\title{
Microbiological Contamination and Disinfection Procedures of Kitchen Sponges Used in Food Services
}

\author{
Eliandra Mirlei Rossi ${ }^{1,2}$, Diane Scapin ${ }^{1}$, Williani Fabíola Grando ${ }^{1}$, Eduardo Cesar Tondo ${ }^{2^{*}}$ \\ ${ }^{1}$ Departamento de Ciências Biológicas e da Saúde, Universidade do Oeste de Santa Catarina, São Miguel do Oeste, Brazil; ${ }^{2}$ Departamento \\ de Ciências dos Alimentos, Instituto de Ciência e Tecnologia dos Alimentos, Universidade Federal do Rio Grande do Sul, Porto Ale- \\ gre, Brazil.

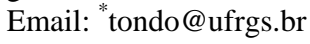

Received May $1^{\text {st }}, 2012$; revised June $1^{\text {st }}, 2012$; accepted June $8^{\text {th }}, 2012$

\begin{abstract}
Kitchen sponges continue to be heavily used in Brazilian food services, even though they may be very contaminated. The objective of this study was to evaluate the microbiological contamination and the efficacy of two procedures for the disinfection of kitchen sponges used in Brazilian food services. Eighty sponges were collected from food services and then analyzed for the quantification heterotrophic microorganisms (HM), fecal coliforms (CF), Staphylococcus coagulase-positive (SA) microorganisms and to the investigation of the presence of Salmonella sp. (SAM). After that, the sponges were disinfected, separately, by either boiling water for five minutes or immersed in 200 ppm sodium hypochlorite, for 10 minutes, added to a rinse with potable water. The results showed that sponges presented HM counts between 3.4 and $10.4 \log$ CFU/sponge, with an average of $9.1 \log$ CFU/sponge, and $76.25 \%$ of them presented CF with average counts of $8.4 \mathrm{log}$ CFU/sponge. SA and SAM were found in $2.5 \%$ of samples. Both disinfection procedures were able to significantly reduce the bacterial counts, but the boiling method showed a greater reduction (99.9999\%) than the method of disinfection by 200 ppm sodium hypochlorite (99.9\%). Based on the results it was possible to conclude that kitchen sponges can be very contaminated, but simple disinfection procedure can be applied to significantly reduce the microbial contamination.
\end{abstract}

Keywords: Kitchen Sponges; Microbiological Contamination; Disinfection; Food Services; Cross-Contamination

\section{Introduction}

Recent years have seen a significant increase in foodborne illnesses worldwide [1,2], including in Brazil [3]. In the United States, it was estimated 38.6 million illnesses each year, and of these 13.8 million were foodborne transmission [4]. In Brazil, according to the Hospital Information System of the Ministry of Health, from 1999 to 2004, there were 3,410,048 hospital admissions due to foodborne illness, with an average of 568,341 cases per year. Additionally, between 1999 and 2002, around 6320 deaths were registered due to these diseases in Brazil [5].

According to data from the Health Surveillance Secretary [5], food services, such as restaurants and schools, were responsible for $18.8 \%$ and $11 \%$, respectively, of the outbreaks which occurred in Brazil from 1999 to 2004.

Kitchen sponges have been recognised as important diffusers of pathogens, and they can cause cross contamination in food [6,7]. These sponges can contain food residues and moisture, and can serve as a reservoir of

${ }^{*}$ Corresponding author. foodborne pathogens such as Escherichia coli, Staphylococcus aureus and Salmonella sp. [1,6,8,9]. Contaminated sponges can transfer pathogens to surfaces that come into contact with food, and these microorganisms can remain viable on these surfaces for hours or days after contamination [9]. Many food services keep their sponges at room temperature, inside containers with water and food residues, which can contribute to microorganism multiplication.

Some disinfection methods have been applied to reduce sponge microbial contamination [10,11]. For the most part, Brazilian legislation does not mention the use of sponges in food services; however, they continue to be used often in these establishments. Because of that, and due to the fact that there are few Brazilian regulations concerning this topic, Regulation 78/2009 of the Rio Grande do Sul State Department of Health, Southern Brazil, has been published stating that sponges in food services must be disinfected daily through boiling in water for 5 minutes [12]. However, the scientific basis for the recommended procedure was not provided. 
The objective of the present study was to evaluate microbiological contamination and two disinfection procedures for sponges that are commonly used in food services, since the number of food service has increased greatly in recent years and in Brazil there are no studies that show to reduce the contamination in the sponges. Thus, this work can be a tool to determine methods for disinfection sponges in food services in Brazil.

\section{Materials and Methods}

\subsection{Sampling}

Eighty polyurethane pad synthetic sponges were collected from food services from the States of Rio Grande do Sul (RS) and Santa Catarina (SC), Southern Brazil. In RS, the sponges were collected from five industrial kitchens from the city of Porto Alegre and in SC the sponges were collected in 35 commercial restaurants from the city of São Miguel do Oeste. In each city, 40 yellow-swith-green pad kitchen sponges were collected. The kitchen sponges collected were in use for at least one day and this information was confirmed by food handlers who were working with them. The sponges were collected with latex gloves and placed in sterile plastic bags, being stored inside cooler boxes at a temperature of $5^{\circ} \mathrm{C}$. The sponges were transported to the Laboratory of Pesquisa e Diagnóstico em Microbiologia of the Universidade do Oeste de Santa Catarina (UNOESC) and the transport time was less than 1 hour.

\subsection{Microbiological Analysis and Disinfection Procedures}

In the laboratory, the sponges were aseptically cut into three equal parts $(4 \mathrm{~cm}$ each). One of them was added to $100 \mathrm{~mL}$ of $0.1 \%$ peptone water containing (AES, Bruz Cedex, France) $0.1 \%$ sodium thiosulphate, and then mixed in a stomacher (ITR, Esteio, RS) for 60 seconds. Later, this part of the sponge was analyzed to HM, CF, SA and SAM, in compliance with Normative Regulation 62 of August $26^{\text {th }}$, 2003 published by the Brazilian Ministry of Agriculture and Food Supply (MAPA) [13]. This is a Brazilian standard methods guide elaborated according to the Compendium of Methods for the Microbiological Examination of Foods-APHA (2001) [14]. The two remaining parts of the sponge were evaluated, separately, after boiling water disinfection for five minutes (in compliance with the Directive 78/2009, SES/RS), and after disinfection with $200 \mathrm{ppm}$ sodium hypochlorite, for 10 minutes. Sponges submitted to $200 \mathrm{ppm}$ sodium hypochlorite disinfection were rinsed with potable water, according to the methods described by Ikawa \& Rossen (1999) [15]. Each sponge part was disinfected in separated glass bottles containing $300 \mathrm{~mL}$ of hypochlorite solution.

The boiling water disinfection was performed inside a microwave oven (Continental, São Paulo, SP), in bottles containing $300 \mathrm{~mL}$ of water, and boiling time was quantified after initiation of bubble formation in the water where the sponges were immersed. The total boiling time was 5 minutes.

The $200 \mathrm{ppm}$ sodium hypochlorite solution was prepared by diluting $10 \mathrm{~mL}$ of a commercial solution of sodium hypochlorite (trade mark Q'Boa) at 2.5\% concentration in $1 \mathrm{~L}$ of sterile water.

After the disinfection procedures, both parts of each sponge were added to $0.1 \%$ peptone water for microbiological analysis. Sponges disinfected with 200 ppm sodium hypochlorite were added to $0.1 \%$ peptone water containing $0.1 \%$ sodium thiosulphate.

The HM counts were carried out by pour-plate technique, using $1 \mathrm{~mL}$ of sample plated in Plate Count Agar (PCA, Merck, Darmstadt, Germany) incubated at $36^{\circ} \mathrm{C} \pm$ $1^{\circ} \mathrm{C}$ by $48 \mathrm{~h}$.

The CF quantification was performed using $1 \mathrm{~mL}$ of sample plated by the overlay technique with Violet Red Bile Agar (VRBA, Merck). The plates were incubated at $36^{\circ} \mathrm{C} \pm 1^{\circ} \mathrm{C}$ by $18-24 \mathrm{~h}$. After incubation, five characteristic colonies were confirmed in EC broth (Merck) incubated at $45^{\circ} \mathrm{C} \pm 0.2^{\circ} \mathrm{C}$ by $24 \mathrm{~h}$. Tubes were gas or effervescence when shaken gently were considered positive.

The SA counts were carried out by spreading $0.1 \mathrm{~mL}$ of sample on plates of Baird-Parker Egg Yolk-Tellurite Agar (DIFCO, Basingstoke). The plates were incubated at $36^{\circ} \mathrm{C} \pm 1^{\circ} \mathrm{C}$ by $48 \mathrm{~h}$. Five characteristic colonies (black with halos) were subjected to Gram staining and biochemical tests for confirmation (catalase, coagulase and thermonuclease (Brasil, 2003).

All counts were carried out in triplicate (three plates per each treatment), and plates containing 25 to 250 colonies were chosen for enumeration. The results were expressed in log CFU/sponge.

For the Salmonella sp. investigation, $25 \mathrm{~mL}$ of $0.1 \%$ peptone water were used, in which the sponge was hydrated after its collection. This aliquot was added to 225 $\mathrm{mL}$ of buffered $1 \%$ peptone water (Merck) and incubated at $36^{\circ} \mathrm{C}$ for 20 hours. After that, $1 \mathrm{~mL}$ of this sample was inoculated into tubes containing selenite-cystine broth (Merck) and tetrathionate broth (Merck). These were incubated at $41^{\circ} \mathrm{C} \pm 0.5^{\circ} \mathrm{C}$ for 24 hours. Then, the typical colonies were isolated onto Brilliant Green Agar and Xylose Lysine Deoxycholate (Merck) and incubated at $36^{\circ} \mathrm{C} \pm 1^{\circ} \mathrm{C}$ for $18-24$ hours. Five characteristic colonies were confirmed by biochemical and serological tests according to Normative Instruction No. 62 of 2003 from the MAPA. The results were expressed as presence or absence.

The microbiological quality of water used for sponge 
rinsing after disinfection with sodium hypochlorite was analysed. Twelve samples of $100 \mathrm{~mL}$ were collected in different points of the Laboratory, using sterile glass bottles added with $0.1 \%$ sodium thiosulphate. Samples were analysed by methods described in Normative Instruction 62 [13]. For coliform analysis, it was used the multiple tube fermentation technique, using lauryl sodium sulfate broth (Merck). The presumptive examination was performed using bile brilliant green (Merck) broth for the enumeration of total coliforms and EC broth (Merck) for fecal coliforms. Results were expressed in MPN/100 mL.

\subsection{Statistical Analysis}

The disinfection procedures were statistically analysed by ANOVA using the Analysis Statistical software, with $p<0.05$ considered significant. The test was used to compare observations of more than two groups simultaneously. ANOVA analysis examined the equality of variances of the data comparing variations between groups and within groups.

\section{Results and Discussion}

\subsection{Sponge Contamination}

The sponges had HM ranging from 3.4 to 10.4 log CFU/ sponge, with an average of 9.1 log CFU/sponge. Among the analysed sponges, 76.75\% (61/80) presented with contamination of HM between 7 and $9 \log$ CFU/sponge. The highest percentage of contaminated sponges by HM (28.75\%) demonstrated approximately 7 log CFU/sponge (Figure 1).

In the present study, the analysis showed that sponges were contaminated, supporting results found by other

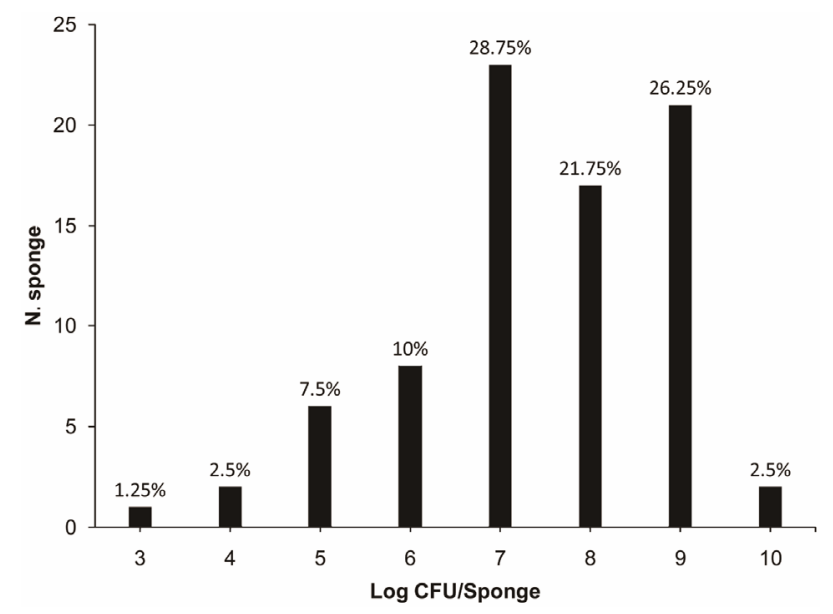

Figure 1. Numbers of sponges containing various levels of contamination of heterotrophic microorganisms (3 to $10 \mathrm{log}$ CFU/sponge) in 80 kitchen sponges that were obtained in food services from the states of Rio Grande do Sul and Santa Catarina. researchers. For example HM contamination was also found by Kusumaningrum et al. [6], who observed approximately $6 \log$ CFU/sponge of HM in sponges used for three days in kitchens in the Netherlands. Also, Erdogrul \& Erbilir [8] found 6.9 log CFU/sponge of HM in sponges used for 10 days in Turkey.

From the evaluated samples, $76.25 \%$ presented with $\mathrm{CF}$, ranging from 4.5 to 9.9 log CFU/sponge, with an average of $8.4 \log \mathrm{CFU} /$ sponge. The highest percentage of sponges with CF contamination (25\%) presented around $7 \log \mathrm{CFU} /$ sponge (Figure 2).

The percentage of sponges contaminated by CF found in the present study was similar to those results reported by Josephson et al. [16] and Ojima et al. [17]. These researchers reported that $67 \%$ of 100 and $78.3 \%$ of 84 sponges collected in the United States and Japan, respectively, were contaminated by CF. Kusumaningrum et al. [6] found approximately 6 log CFU/sponge of CF in kitchen sponges in the Netherlands.

CF in kitchen sponges indicates the presence of faecal material and may indicate the presence of food pathogens [6]. CF contamination in sponges can be attributed to different factors, such as inappropriate hygienic and sanitary practices during food preparation, contamination by raw products, absence of disinfection procedures, cross contamination due to contaminated food and storage of sponges in places with high humidity and adequate temperature to promote microbial growth.

When the average counts of HM and CF were compared, and the percentage of these microorganisms found in sponges were considered, one may suggest that an expressive proportion of the microbiological contamination present in the sponges was, in fact, of faecal origin.

SA and SAM were found in $2.5 \%$ of the samples

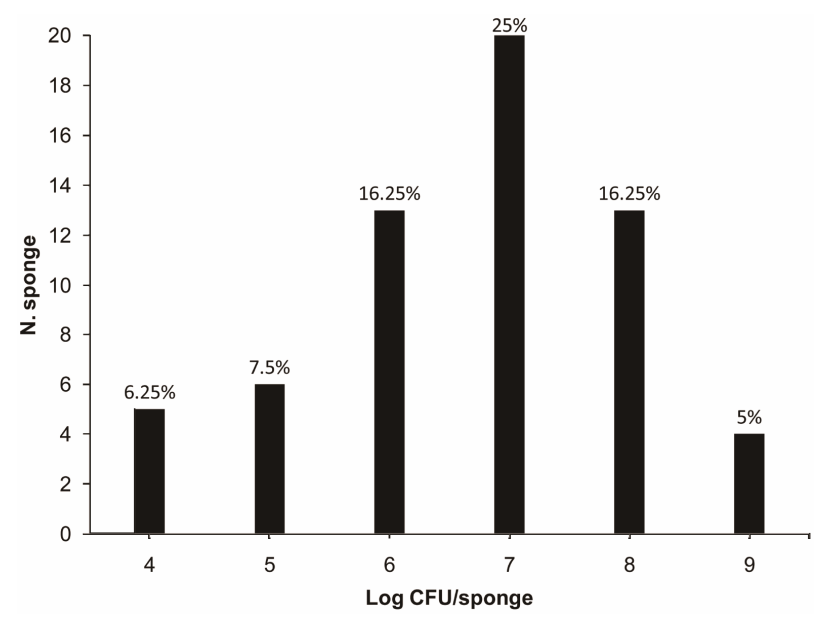

Figure 2. Numbers of sponges containing various levels of contamination of coliforms at $45^{\circ} \mathrm{C}$ (4 to $9 \log \mathrm{CFU} /$ sponge) in 80 kitchen sponges that were obtained in food services from the states of Rio Grande do Sul and Santa Catarina. 
(2/80), with SA at 3.6 and SAM at 5.3 log CFU/sponge. The samples that were contaminated by SA and SAM were different sponges.

It is necessary to emphasize that the low frequency of the pathogens SA and SAM in these sponges was also found in other studies [8]. Even though they were less frequent in sponges, they are the main pathogens responsible for foodborne illnesses in many countries [1], including Brazil [5].

Although sponges are used through direct contact with the staff's hands and it is known that humans have SA on their skin [18], only $2.5 \%$ of samples had these microorganisms. This low percentage of samples contaminated by SA can be attributed to the inhibitory effect of detergents present on the sponges, which was visually demonstrated in many samples after sampling from food services (results not reported because the observation was made visually). According to Kusumaningrum et al. [6], the Gram-positive bacteria, such as SA, have a cell wall which is more sensitive to anionic surfactants present in detergents, which can contribute to the inactivation of these microorganisms. Other fact that can explain the low percentage of SA in sponges is that this microorganism is not a good competitor in the presence of other bacteria, such as coliforms [19].

Many studies have shown that kitchen sponges can be potential sources of cross contamination, including the spread of pathogen microorganisms $[8,9,20]$.

During the cleaning process of equipment, utensils and sinks in domestic kitchens or commercial food services the use of sponges are very frequent. Cleaning processes aim to eliminate food residues present on surfaces, but as a normal consequence of this procedure, part of the residues adheres to the sponge surfaces. These food residues together with the moisture retained in the sponges offer a favorable environment for bacterial growth [8], increasing the risk of microbiological contamination.

\subsection{Disinfection Procedures}

Even though both disinfection methods significantly reduced the counts of HM $(p<0.05)$, the boiling method was the most effective in inactivating microorganisms. The boiling method was able to reduce the counts by 6.7 log CFU/sponge (99.9999\%), while the disinfection by sodium hypochlorite $200 \mathrm{ppm}$ for 10 minutes added in a rinse in potable water reduced the HM counts by $2.7 \mathrm{log}$ CFU/sponge (99.9\%) (Figure 3).

The average reductions of $\mathrm{CF}$ reached after boiling and sodium hypochlorite disinfection were $8.4 \log \mathrm{CFU} /$ sponge (99.999999\%) and $2.1 \mathrm{log} \mathrm{CFU} / \mathrm{sponge}$ (99\%), respectively. CF was not detected after boiling, while 6.3 $\log \mathrm{CFU} /$ sponge survived after sodium hypochlorite disinfection.

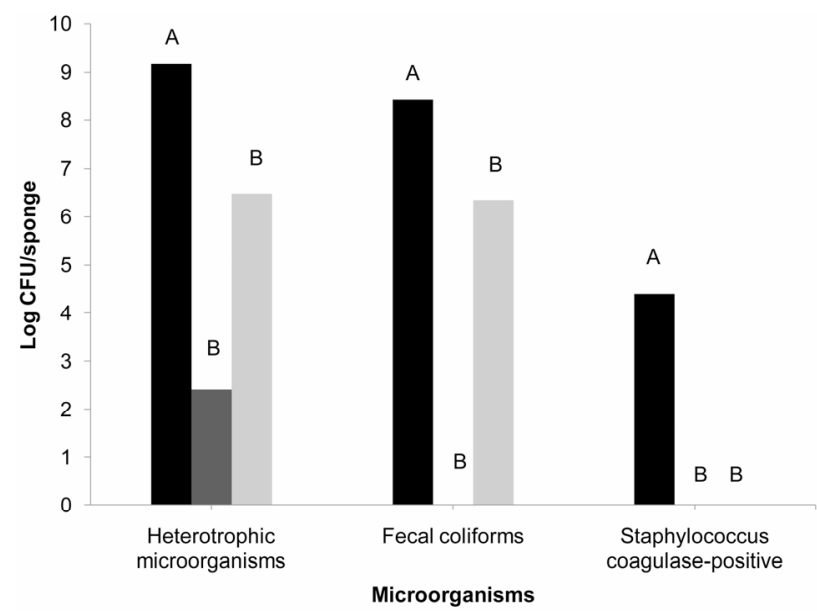

Figure 3. Bacterial reduction (log CFU/sponge) in collected sponges of food services not disinfected $(\square)$, disinfected by boiling in a microwave for 5 minutes $(\square)$, and after disinfection with $200 \mathrm{ppm}$ sodium hypochlorite for 10 minutes, added to a rinse of potable water $(\square)$. Different letters indicate statistically significant reductions $(p<0.05 \%)$.

After both methods, SA and SAM were not found on the sponges.

All water samples analyzed and used to rinse the sponges after disinfection with 200 ppm sodium hypochlorite showed absence of total and fecal coliforms.

The two methods of disinfection analyzed in this study were significantly effective in the reduction of bacteria in sponges. Nevertheless, the boiling method was able to reduce the greatest number of microorganisms. Similar results were presented by Sharma et al. [11], who found significant reductions $(p<0.05 \%)$ after disinfection with a $10 \%$ solution of sodium hypochlorite for three minutes, and boiling in a microwave oven for one minute, which obtained a better result when compared to the sodium hypochlorite treatment.

The reductions in HM found by Sharma et al. [11] were of $7.1 \log$ and $1 \log \mathrm{CFU} /$ sponge for disinfection by boiling inside a microwave oven and $10 \%$ sodium hypochlorite, respectively. The lowest microbial reduction verified after the use of sodium hypochlorite could be explained by the presence of organic matter in the sponges $[6,11,21]$. On the other hand, the results of the present study showed that some sponges (7/80) still retained viable microorganisms after boiling, which can be explained by the probable presence of heat-resistant sporeforming microorganisms [21].

According to Celandroni et al. [22], even if these microorganisms easily survive boiling, this process can eliminate part of the microbial population, depending on the strains present. For example, microwave boiling was more effective than conventional boiling for the inactivation of Bacillus subtilis. According to these authors, the inactivation of endospores occurs due to the formation of 
a stable complex between the dipicolinic acid and other components of the endospore.

The effectiveness of CF inactivation was verified in both methods, but the boiling reduced 99.999999\% of these bacteria in sponges, while the sodium hypochlorite reduced counts by 99\%. According to Ikawa and Rossen [15], boiling for five minutes is an excellent method for the disinfection of sponges, drastically reducing the amount of CF.

The efficiency of the boiling method can be explained by the high temperature of the water which is able to denature proteins and, consequently, destroy the cell membrane integrity, causing the death of microorganisms [23].

In the present study, the sponges were immersed in water, therefore microbial reduction probably occurred due to the heat of the water $[11,24]$.

In the microwave, the heat that causes the inactivation of microorganisms arises from the movement of water molecules from the electromagnetic waves [25]. The energy transfers utilizing microwaves to the material to be heated-up are by means of conduction, convection and irradiation while microwaves interact directly with the material, causing temperature increases due to the interaction of the molecular electric fields with the electromagnetic waves at their different phases and producing ionic conduction and dipolar rotation [25].

Additionally, another important factor to be emphasised is that during water boiling, the sponge moves around within the liquid, making the removal of a great deal of organic matter possible and, with that, better heat penetration. This movement did not happen during the evaluation of the solution of 200 ppm sodium hypochlorite, which could have resulted in the lower inactivation of microorganisms.

Based on the results, it was possible to conclude that kitchen sponges can be expressively contaminated, but there are effective methods for their disinfection. Although both methods analysed in the present study significantly reduced the bacterial counts, boiling for five minutes was more effective than disinfection in 200 ppm sodium hypochlorite. These results showed the adequacy of the boiling method recommended by the Directive 78/2009SES/RS [12] for the disinfection of sponges in food services of the State of Rio Grande do Sul, Brazil. Furthermore, this method proved to be easy and affordable in terms of cost, and can be performed in food services and in residences.

\section{REFERENCES}

[1] A. H. Havelaar, S. Brul, A. R. De Jong, R. De Jonge, M. H. Zwietering and B. H. Terkuile, "Future Challenges to Microbial Food Safety,” International Journal of Food Microbiology, Vol. 139, 2009, pp. S79-S94. doi:10.1016/j.ijfoodmicro.2009.10.015

[2] J. K. Ikawa and J. S. Rossen, "Reducing Bacteria in Household Sponges,” Environmental Health, Vol. 62, No. 1, 1999. pp. 18-22.

[3] F. A. De Oliveira, M. P. Geimba, A. P Pasqualotto, A. Brandelli, G. Pasquali, W. P Da Silva and E. C. Tondo, "Clonal Relationship among Salmonella enterica Serovar Enteritidis Involved in Foodborne Outbreaks in Southern Brazil,” Food Control, Vol. 20, No. 6, 2009, pp. 606-610. doi:10.1016/j.foodcont.2008.08.014

[4] M. Ojima, Y. Toshima, E. Koya, K. Ara, H. Tokuda, S. Kawai, F. Kasuga and N. Ueda, "Hygiene Measures Considering Actual Distributions of Microorganisms in Japanese Households," Journal of Applied Microbiology, Vol. 93, 2002, pp. 800-809.

doi:10.1046/j.1365-2672.2002.01746.x

[5] M. Sharma, J. Eastridge and C. Mudd, "Effective Household Disinfection Methods of Kitchen Sponges," Food Control, Vol. 20, No. 3, 2009, pp. 310-313.

doi:10.1016/j.foodcont.2008.05.020

[6] R. Lindqvist, S. Sylvén and I. Vagsholm, "Quantitative Microbial Risk Assessment Exemplified by Staphylococcus aureus in Unripened Cheese Made from Raw Milk," International Journal of Food Microbiology, Vol. 78, No. 1-2, 2002, pp. 155-170. doi:10.1016/S0168-1605(02)00237-4

[7] P. S. Mead, L. Slutsker, V. Dietz, L. F. McCaig, J. S. Bresee, C. Shapiro, P. M. Griffin and R. V. Tauxe, "FoodRelated Illness and Death in the United States," Emerging Infectious Diseases, Vol. 5, No. 5, 1999, pp. 607-625. doi:10.3201/eid0505.990502

[8] O. Erdogrul and F. Erbilir, "Microorganisms in Kitchen Sponges,” Journal of Food Safety, Vol. 6, 2005, pp. 1722.

[9] H. D. Kusumaningrum, M. M. Van Putten, F. M. Rombouts and R. R. Beumer, "Effects of Antibacterial Dishwashing Liquid on Foodborne Pathogens and Competitive Microorganisms in Kitchen Sponges," Journal of Food Protection, Vol. 65, No. 1, 2002, pp. 61-65.

[10] R. R. Beumer and H. Kusumaningrum, "Kitchen Hygiene in Daily Life," International Biodeterioration Biodegradation, Vol. 51, No. 4, 2003, pp. 299-302. doi:10.1016/S0964-8305(03)00041-6

[11] G. M. Tebbutt, "Does Microbiological Testing of Foods and the Food Environment Have a Role in the Control of Foodborne Disease in England and Wales?” Journal of Applied Microbiology, Vol. 102, No. 4, 2007, pp. 883891.

[12] Brasil, Portaria No. 78 de 28 de Janeiro de 2009 da Secretaria Estadual de Saúde do Estado do Rio Grande do Sul, “Aprova a Lista de Verificação em Boas Práticas para Serviços de Alimentação, Aprova as Normas Para os Cursos de Capacitação em Boas Práticas Para Serviços de Alimentação e dá Outras Providências,” Diário Oficial da União, Porto Alegre, 2009.

[13] Brasil, Instrução Normativa No. 62 de 26/08/2003, “Oficializa os Métodos Analíticos Oficiais Para Análises Microbiológicas Para Controle de Produtos de Origem Animal e Água,” Diário Oficial da União, Brasília, 2003. 
[14] American Public Health Association (APHA) "Compendium of Methods for the Microbiological Examination of Foods," 4th Edition, APHA, Washington DC, 2001, p. 676.

[15] K. L. Josephson, J. R. Rubino and I. L. Pepper, "Characterization and Quantification of Bacterial Pathogens and Indicator Organisms in Household Kitchens with and Without the Use Disinfectant Cleaner," Journal of Applied Microbiology, Vol. 83, No. 13, 1997, pp. 737-750. doi:10.1046/j.1365-2672.1997.00308.x

[16] Z. A. Kanafani and V. G. Fowler Jr, "Staphylococcus aureus Infections: New Challenges from an Old Pathogen,” Enfermedades Infecciosas y Microbiología Clínica, Vol. 24, No. 3, 2006, pp. 182-193.

[17] D. K. Park, G. Bitton and R. Melker, "Microbial Inactivation by Microwave Radiation in the Home Environment," Journal of Environmental Health, Vol. 69, No. 5, 2006, pp. 17-24.

[18] K. L. Kotula, A. W. Kotula, B. E. Rose, C. J. Pierson and M. Camp, "Reductions of Aqueous Chlorine by Organic Material," Journal of Food Protection, Vol. 60, No. 3, 1997, pp. 276-282.

[19] K. Mattick, K. Durham, G. Domingues, F. Jørgensen, M. Sen, D. W. Schaffner and T. Humphrey, "The Survival of Foodborne Pathogens during Domestic Washing-Up and Subsequent Transfer onto Washing-Up Sponges, Kitchen Surfaces and Food," International Journal of Food Mi- crobiology, Vol. 85, No. 3, 2003, pp. 213-226. doi:10.1016/S0168-1605(02)00510-X

[20] Secretaria de Vigilância em Saúde, "Boletim Eletrônico Epidemiológico,” No. 6, 2005.

http://portal.saude.gov.br/portal/arquivos/pdf/bol_epi_6_2 005_corrigido.pdf

[21] H. D. Kusumaningrum, G. Riboldi, W. C. Hazeleger and R. R. Beumer, "Survival of Foodborne Pathogens on Stainless Steel Surfaces Cross-Contamination to Foods," International Journal of Food Microbiology, Vol. 85, No. 3, 2003, pp. 227-236. doi:10.1016/S0168-1605(02)00540-8

[22] F. Celandroni, I. Longo, N. Tosoratti, F. Giannessi, E. Ghelardi, S. Salvetti, A. Baggiani and S. Senesi, "Effects of Microwave Radiation on Bacillus subtilis Spores," Journal of Applied Microbiolology, Vol. 97, No. 6, 2004, pp. 1220-1227. doi:10.1111/j.1365-2672.2004.02406.X

[23] A. O. Valsechi, J. Horii and D. Angelis, "The Effect of Microwaves on Microorganisms,” Arquivos do Instituto Biológico, São Paulo, Vol. 71, 2004, pp. 399-404.

[24] E. Scott, "Hygiene Issues in the Home,” American Journal Infection Control, Vol. 27, No. 6, 1999, pp. S22-S25. doi:10.1016/S0196-6553(99)70038-6

[25] A. O. Valsechi, J. Horii and D. Angelis, "The Effect of Microwaves on Microorganisms," Arquivos do Instituto Biológico, São Paulo, Vol. 71, 2004, pp. 399-404. 